\title{
Stone tools in the High Molise Mountains (Italy): A first report
}

\author{
Vittorio Mironti, Melissa Vilmercati, Enrico Lucci, Rachele Modesto \\ Dipartimento di Scienze dell’Antichità, Sapienza University of Rome, Piazzale Aldo Moro, 500185 \\ Rome Italy. Email: Mironti: v.mironti@gmail.com; Vilmercati: melissa.vilmercati@uniroma1.it; \\ Lucci: enrico.lucci@uniroma1.it; Modesto: rachele.modesto@gmail.com
}

\begin{abstract}
:
In the last decades, several researches focused on the inland areas of Molise Region (CentralSouthern Italy) to investigate the occupation and exploitation of this environment during Pleistocene and Holocene.

The "Molise Survey Project" started in 2015 with the aim to explore, through systematic surveys, an area of 60 square kilometres, chiefly characterized by a mountainous landscape and part of the Central-Southern Italy Apennines. The project seeks to investigate the patterns of human occupation in the mountainous landscape between the provinces of Campobasso and Isernia. The surveys, carried out during the last four years, allowed the identification of 19 prehistoric sites ranging from Palaeolithic to Bronze Age: the archaeological materials belonging to the latter period are being studied by the team of "Paletnologia" of Sapienza University of Rome. This work aims to show the preliminary results of the analysis of the lithic assemblage acquired during the summer of 2016 surveys, focusing on raw material procurement and the related chaîne opératoire, also considering post-depositional agents. The obtained data allowed to reassess the human presence over inland and high-altitude areas of Molise during prehistoric times, stressing a seasonal use of the territory, from Palaeolithic to late prehistory, with different patterns of occupation and exploitation.
\end{abstract}

Keywords: Stone tools; Italian prehistory; Molise region; mountains; central-southern Italy

\section{Introduction}

The main purpose of this project is the comparison of raw materials procurement strategies and lithic production in the high mountains of central Italy Apennine during different phases of prehistory.

Many other projects focused on the great valleys that connect the coast to the inland areas, e.g. Biferno Valley (Barker 1989, 1995a: 1-40, 1995b: 1-58), Sangro Valley (Lock 2008, Lock \& Faustoferri 2008), on great lake basins within the Apennines, Fucino Lake (Ialongo 2007: 19-148) and on other areas potentially attractive for human presence. However, the exploitation of the mountainous landscape in the High Mountains of the Italian Apennine during prehistory remain still largely unknown, especially for contexts over $1000 \mathrm{~m}$ 
a.s.l. In Molise, some surveys and excavations confirmed the hypothesis of human presence in the region since Lower-Middle Palaeolithic, e.g. Sessano del Molise, San Lorenzo, Pescopennataro, Capracotta, etc. (Grimaldi 2005: 1-126; Peretto \& Minelli 2006: 251-355). For Lower Palaeolithic, the most known site is Isernia La Pineta, situated at $450 \mathrm{~m}$ a.s.l. and occupied since 610,000 years BP (e.g. Coltorti et al. 1982; Cremaschi \& Peretto 1988; Anconetani et al. 1992; Minelli \& Peretto 2000; Peretto 2013: 1-124), while a key site at the Lower-Middle Palaeolithic transition is Guado San Nicola dated to 400,000 years BP and situated at $250 \mathrm{~m}$ a.s.l (Peretto et al. 2016); finally, for Middle Palaeolithic, the site of Grotta Reali (at 515 m a.s.l.) should be mentioned and dated to 40.000 years BP (Peretto 2012: 3940).

The "Molise Survey Project" started in 2015 with the intent of understanding the strategies of human occupation in the areas above $1000 \mathrm{~m}$ a.s.l. The project, carried out by the team of "Paletnologia" of Sapienza University of Rome since 2016 (Lucci et al. 2016; Cazzella et al. 2017, 2018a, 2018b), concerns an area of about 60 square kilometres on the mountain range (divided into squares by $1 \mathrm{~km}^{2}$ and 5 transepts with irregular dimensions), West of the town of Frosolone (Isernia, Central-Southern Italy) (Figure 1). Since 2008, the sample area hosts the Enel wind farm in Acquaspruzza which strongly altered the surrounding landscape, with the installation of dozens of wind turbines (Cazzella et al. 2018a).

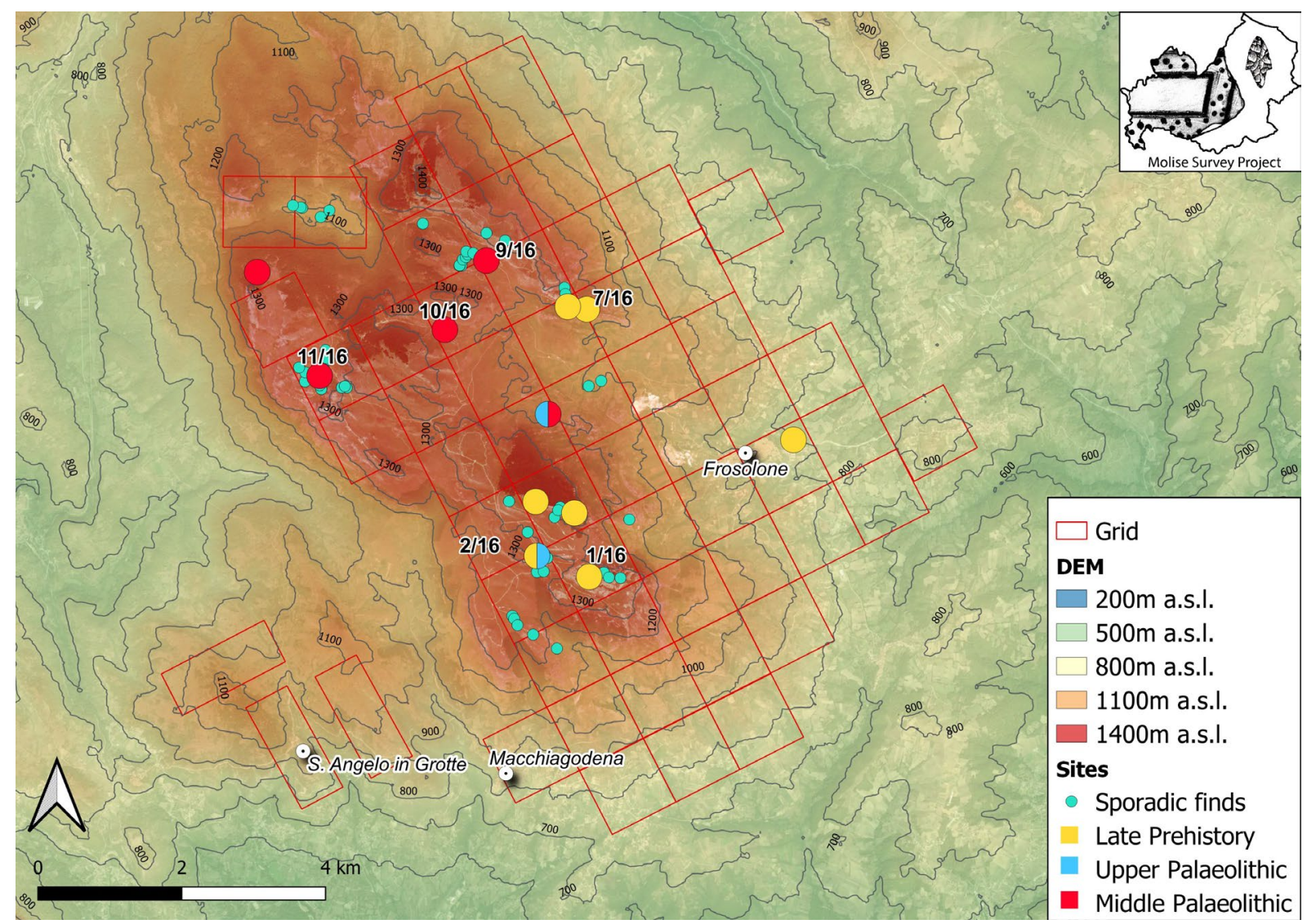

Figure 1. The archaeological sites discovered during the survey activities of 2016: the site codes highlight the presence of lithic artefacts.

The Frosolone mountain (Isernia, Central-Southern Italy) is characterized by a very articulate physiography with rocky spurs that reach $1400 \mathrm{~m}$ a.s.l., deep valleys and small lake basins, subject to seasonal variations (Figure 2). It is plausible that during Interglacial phases and warmer months of the year this environment was suitable for human groups occupation (Cazzella et al. 2018a). The presence of flint deposits could constitute a further reason for 
human attendance. During our fieldwork, we tried to identify the possible sources of this raw material and the subsequent lithic reduction schemes.

This report aims to present the first results of "Molise Survey Project". A large part of the data acquired during the fieldwork are still under scrutiny.
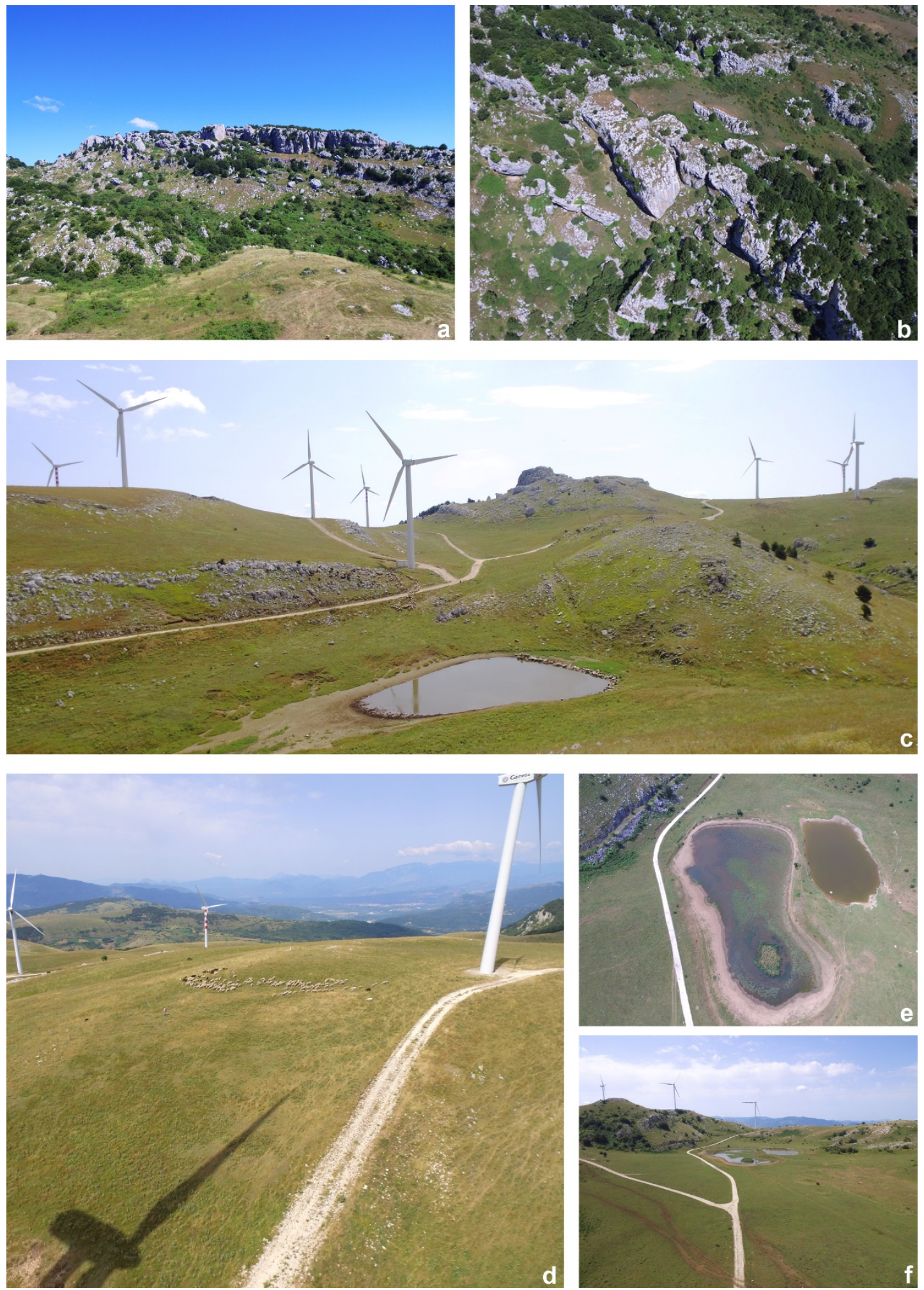

Figure 2. a: The Rocky Wall of Morgia Quadra (Frosolone, Isernia); b: The rocky spurs of Bronze Age settlement of Morgia Quadra (Frosolone, Isernia); c: The rocky spur of Bronze Age settlement of Pesco La Messa and lake of Acquaspruzza (Frosolone, Isernia); d: A shepherd at Pesco La Messa (Frosolone, Isernia); e and f: The Lake of Carpinone (Carpinone, Isernia). 


\section{Materials and Methods}

Our fieldwork is organized as follows: every day a team composed by a maximum of 10 people choose one square $\left(1 \mathrm{~km}^{2}\right)$ to surveying on foot. The distance between the surveyors, usually ranging from 2 to $10 \mathrm{~m}$, is closely related to the physiographic and topographic situations and to the conditions of visibility of the ground. During the survey, to every archaeological find is assigned a code corresponding to the GPS point of its discovery.

The fieldwork allowed us to identify 492 prehistoric contexts with a chronology ranging from Middle Palaeolithic to Bronze Age. When the archaeological evidences were concentrated in a particular area, we considered that as an archaeological site, to which we assigned a sequential number followed by the year of discovery (Figure 1). The lithic assemblage subject of this paper comes from the survey activities of 2016, carried out in sites placed above $1000 \mathrm{~m}$ a.s.l., while the archaeological materials found in 2017 and 2018 campaigns are under study.

The total amount of the analysed lithic artefacts is 181 and includes: 148 retouched elements, 28 unretouched and 5 cores (Figure 3). The ratio between retouched and unretouched pieces is particularly unbalanced toward the first class because of the effect of postdepositional alterations. Indeed, due to patina, fissures, erosive phenomena of the edges etc. the lithic artefacts are scarcely distinguishable from natural rocks. In this regard, during our fieldwork we often found some lithic pieces with pseudoretouched edges that don't seem realized by chipping: the total amount also includes those pieces, though this aspect will be better investigated with the continuation of the project. Finally, it must be specified that during our survey no flint processing areas were found.

As regards lab activities the analysis of the lithic assemblage starts with a macroscopic study of raw material, trying to identify any variables in the lithological composition: whether or not there is a cortex, the physical appearance, state of conservation, state of alteration, presence or not of patina, traces of oxidation, etc. To better understanding the chronological attribution of the sites under scrutiny, the analysis of the lithic artefacts was carried out with a techno-typological approach, considering the features associated with the various knapping techniques and methods. In this respect, the retouched elements were described using a very flexible typology.

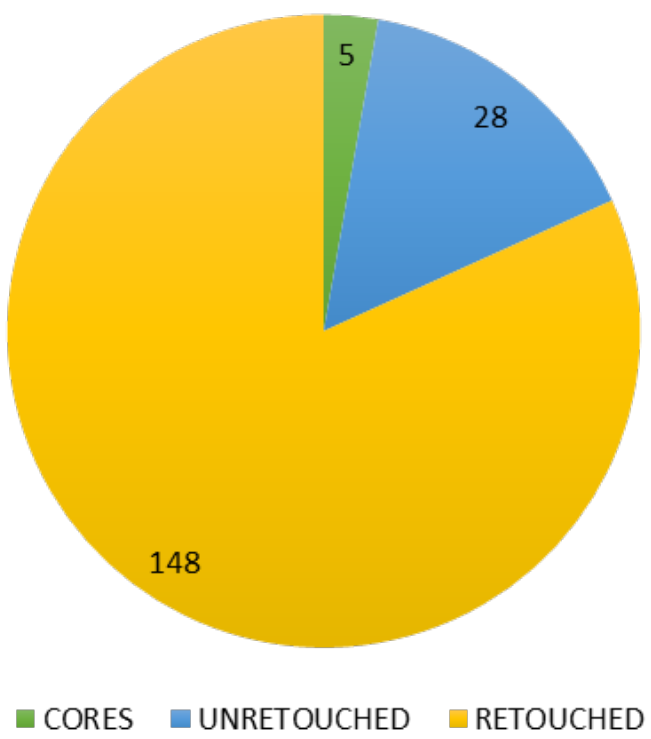

Figure 3. A preliminary division of the lithic assemblage from the 2016 campaign. 
Later, attempting to clarify the possible function of the artefacts, we used a morphofunctional approach (Boëda 2013: 16-46), but the results of this analysis are not included in this paper.

The macroscopic analysis of the lithic sample was possible with a database, already experienced for this class of artefacts coming from the 2015's surveys (Lucci et al. 2016). The data entry activity: GPS point of the find, type and the source of raw material, number and morphology of the artefacts, knapping methods (considering both flakes, blades and cores), typology and finally the surface alterations. In the same database were also analysed the macrolithic tools. Subsequently, all the data were processed using Excel tables. The recording of these features permitted to reconstruct the various phases of the chaîne opératoire, specifically: initial stages, shaping, production, use and abandonment. This was the starting point to investigate the exploitation of this areas during Pleistocene and Holocene.

\section{First Results}

\subsection{Raw materials}

Firstly, was carried out the provenance analysis of raw material: according to the geologic map of Molise (Vezzani et al. 2006), the Frosolone mountain is located in an area comprehending different geological conditions alternating layers of limestones, marl limestones and marls with limestone and dolostone deposits. The latter formations are of fundamental importance for the abundant presence of flint.

Despite the recurrent presence of a very invasive patina that in some cases does not allow to trace back to the lithological characteristics of raw material, we were able to observe the colour of the flint that varies from red, white and black to grey (both dark and light) and, in some cases, to brown. The texture is not totally homogenous and, in some cases, shows a rather coarse granulometry, both factors that prevent an easy chipping. In addition, the flint is often degraded due to the frequent tectonics movements, but mostly to the thermic alteration, especially to the freeze-thaw phenomenon (which occur very often in the area) that creates internal macrofissures. Finally, the artefact morphology and residual cortex analysis led us to think that the raw material was probably collected in primary deposits, where it can be found in form of bands and, less often, in form of nodules.

Although we are awaiting the results of geochemical analyses, our hypothesis has been partially corroborated from fieldwork: inside massive limestone deposits, there are many raw material sources of modest size, yielding a low quality flint, but still workable. Moreover, indepth studies on raw materials have already been carried out in other sites in the Isernia's province, like San Mauro, Vastogiradi, Capracotta (Peretto \& Minelli 2006: 251-355), Ficora di Morra (Vilmercati 2017: 22-26), with which is possible to make a close comparison.

With the continuation of research, we will try to figure out the precise provenance of the flint and whether strictly local or exogenous flint was used.

\subsection{The lithic sample}

The lithic assemblage comes from 7 of the 12 archaeological sites discovered during the 2016 survey, but also from 10 GPS points that yielded sporadic evidences (Table 1, Figure 4). The 7 prehistoric sites are attributable to different chronological phases, indicating the prolonged occupation and reoccupation of these territories: 4 sites can be dated to Middle Palaeolithic, 2 to Upper Palaeolithic and finally, 3 sites to late prehistory (NeolithicEneolithic period and Bronze Age) (Figure 1). 
Table 1. The artefacts with certain chronological determination are divided according to the contexts of discovery. The table shows the numerical values of the artefacts.

\begin{tabular}{llll}
\hline Site & Cores & Unretouched & Retouched \\
\hline $1 / 16$ (Pesco la Messa) & 1 & 1 & 3 \\
2/16 (Acquaspruzza Lake) & & 3 & 7 \\
$6 / 16$ (Cannavine Lake) & & 2 & 3 \\
$7 / 16$ (Morgia Quadra) & & 1 & 1 \\
$9 / 16$ (Cervaro Lake) & & 2 & 16 \\
$10 / 16$ (Castrati Lake) & & & 6 \\
$11 / 16$ (Carpinone Lake) & 3 & 2 & 55 \\
Off-site & & 2 & 17 \\
\hline
\end{tabular}

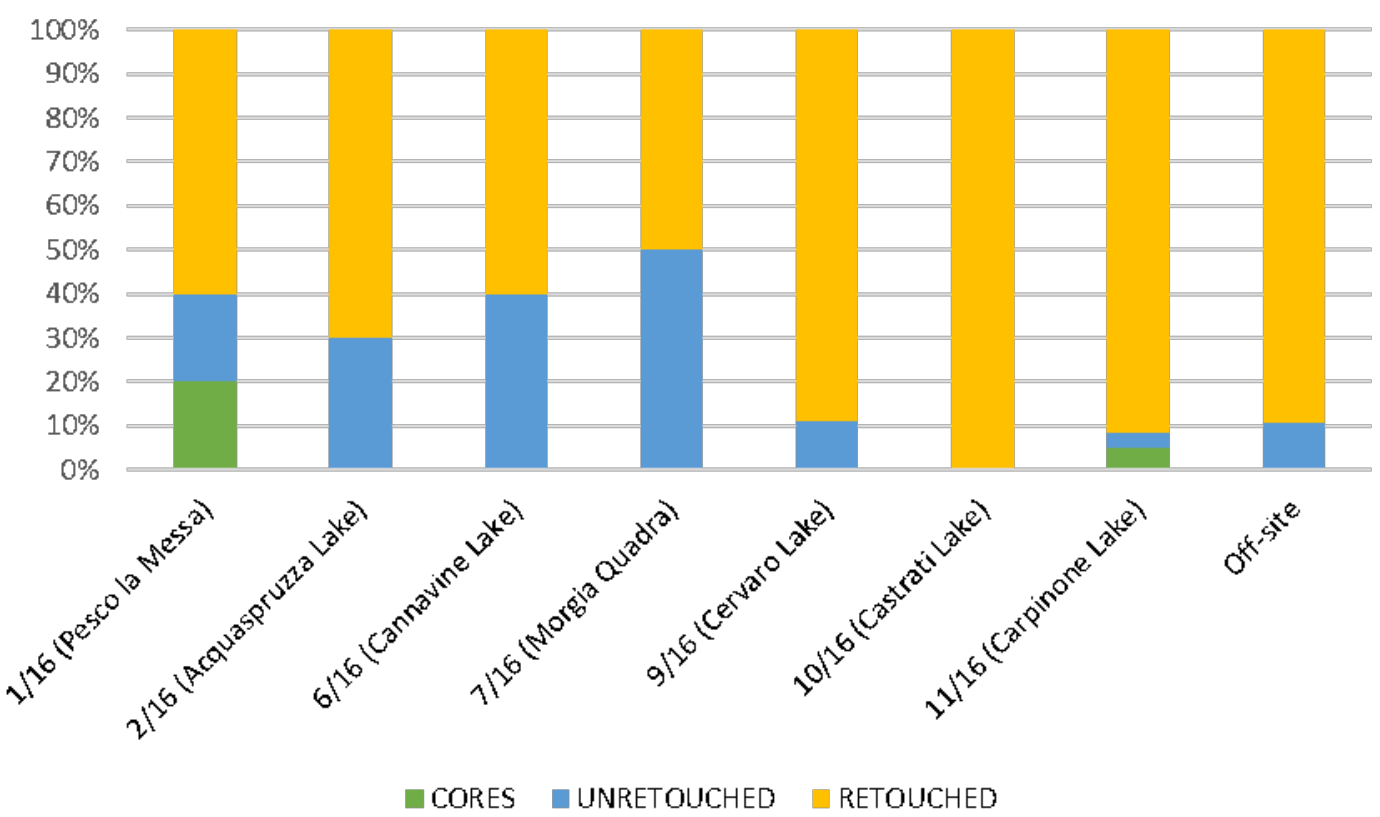

Figure 4. The artefacts with certain chronological determination divided according to the discovery contexts: a. percentage of element typology site by site.

A certain chronological determination was possible on 125 artefacts of the lithic sample, attesting the presence of human groups in this area during the entire prehistory; most of the tools are attributable to Mousterian industries while few artefacts, related to laminar productions, are probably referred to the subsequent periods. An important peculiarity concerns the sites with the largest lithic sample, that are located on the shores of small mountain lakes: in future researches we will try to define the possible moments of attendance of neanderthals and sapiens groups during glacial and interglacial phases.

An amount of 100 lithic elements is datable to Middle Palaeolithic (Figure 5 a-f). The most recurring feature in the analysed samples of this period is a peculiar yellow and brown patina. Most of these artefacts are retouched pieces (89 to 100) as scrapers, denticulates and retouched flakes, with more or less rounded edges. In most cases the Middle Palaeolithic tools are knapped with the Levallois method: the presence of preferential, recurring and centripetal Levallois method - both for flakes and points - led us to think that, despite the low quality of raw material, neanderthal flint chippers were very experienced and able to use all the different aspects of the method.

The knowledge concerning the evidences of Upper Palaeolithic (Figure $5 \mathrm{a}-\mathrm{f}$ ) is still very incomplete: there are only 12 artefacts from this period, recognisable thanks to the peculiar 
white colour of the patina and to the very sharp edges. There are only two unretouched pieces, while, most of the tools are retouched blades, witnessing the start of the use of this specific knapping method. The few other tools, mostly scrapers and notches, are often produced on laminar supports.

Finally, the lithic assemblage related to late prehistory (Figure 5 g-n) is constituted by 10 tools, 2 unretouched artefacts and 1 undifferentiated core, all characterized by a total absence of patina and relatively sharp edges. The tools were often produced by laminar supports (retouched blades); the most interesting pieces are surely three arrowheads, that could represent a type of recurring artefact of the late prehistory in Frosolone mountain, their possible function was probably related to hunting or war purposes. Regarding the two unretouched artefacts, one is a rejuvenation of a laminar core, while the second is a thick flake for the core preparation (covered with cortex on more than the half of its surface), these samples witness the local production of the lithic industries.
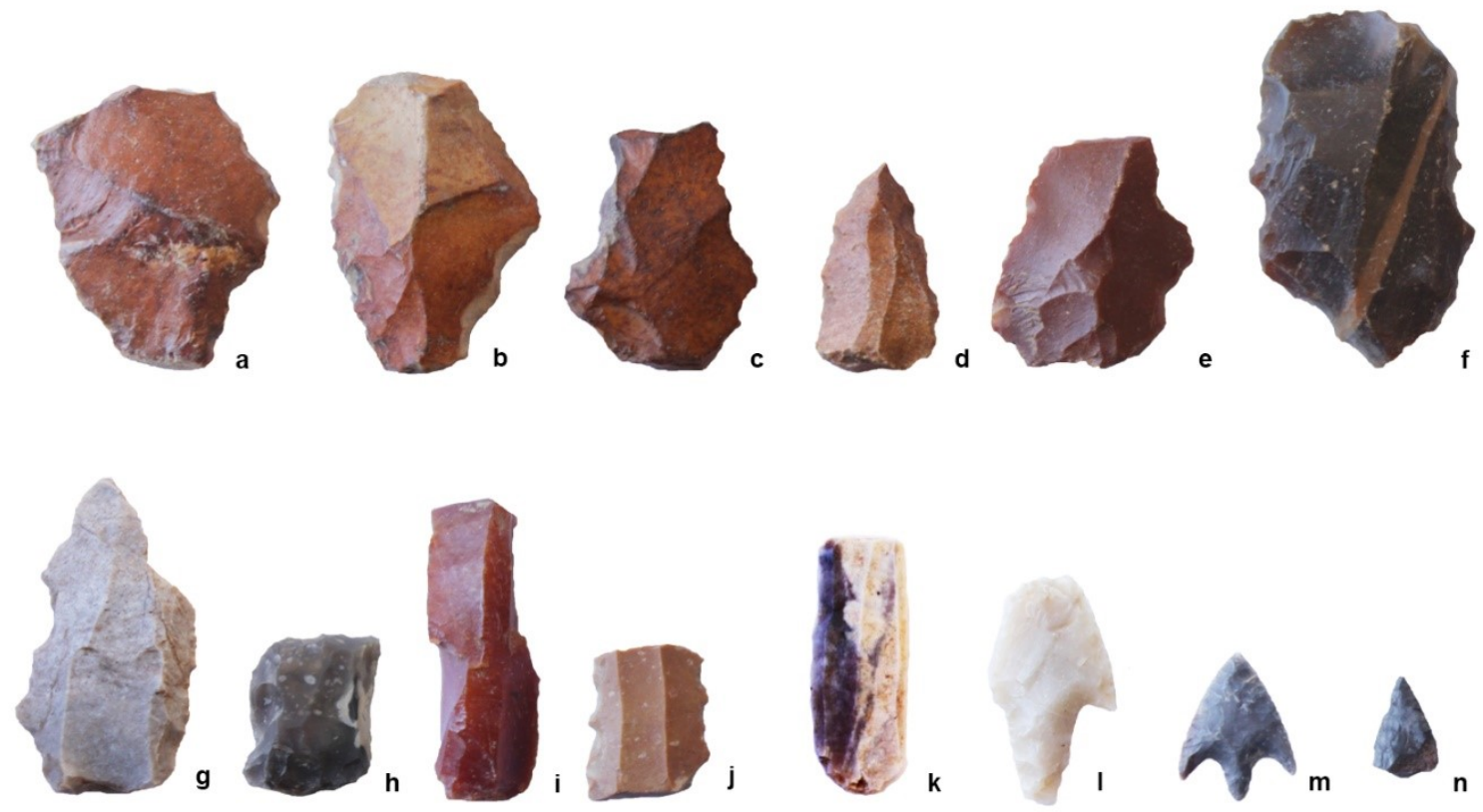

Figure 5. a-f: artefacts ascribable to the Palaeolithic (most are Levallois elements referable to the Middle Palaeolithic); g-n: finds of late prehistory (rejuvenations of laminar cores, retouch blade, blade and arrowheads).

\section{Preliminary conclusions and future research perspectives}

The lithic tools related to the different phases of prehistory show differences and similarities that will be better analysed during the continuation of the project. Another purpose of the future research is to carry out both systematic excavations and paleoenvironmental analyses, necessary to understand the time frames of neanderthals and sapiens attendance on mountain lake basins. Those different approaches will led to a more precise knowledge of human prehistoric occupation on a regional scale.

However, the data collected during the 2016 surveys, have already contributed to an advancement of knowledge in this sense. Given the altitude of the discovered sites -ranging from $1100 \mathrm{~m}$ to $1400 \mathrm{~m}$ a.s.l. (Figure 1)- our data concur to hypothesize new settlement patterns of human groups in the inland areas of Molise region, adding new information to the already known interpretative models of the prehistory of Italian peninsula (Puglisi 1959: 15- 
20). In fact, basing on our new archaeological evidences, we can now assume that fairly humid environment at high altitude, as the one of Frosolone mountain, could be a pivotal area over the territory for human groups during the entire prehistory. In this sense, the analysed artefacts stress a chronological continuity in reoccupation of these areas, that probably were strategically important both for the hunter-gatherers and agro-pastoral groups. The first maybe chose these areas, dominating the wide valleys below, for the availability of most of their daily needs (water, raw materials, etc.). Most of all, Paleolithic human groups probably moved at these areas during summer or in interglacial phases to follow groups of animals to hunt.

On the other hand, during late prehistory, human groups probably chose these areas also to take advantage of their natural defensive position, most of these sites are indeed very difficult to reach due to the steep slope of the mountain. Moreover, agricultural activities in high altitude environments cannot be excluded. Finally, especially Bronze Age communities could use summer mountain pastures and wide areas for the practice of transhumance -mobile herding-, a habit that both in historical times and nowadays is strongly rooted in Molise's societies, we are referring to the phenomenon of tratturi (Sprengel 1971: 40-135), which can probably retrace ancient routes, used for the same purpose.

\section{Acknowledgements}

We are very grateful to Alberto Cazzella, Maurizio Moscoloni and Giulia Recchia, all affiliated to the Sapienza University of Rome, for coordinating this archaeological research. Some special thanks go also to the SABAP of Molise region. We are also very grateful to the Comune of Oratino and Comune of Frosolone for hosting and welcoming us during the surveys. Huge thanks go also to all the participants of Molise Survey Project for having contributed to the growth of the mission with their hard work on field.

\section{References}

Anconetani, P., Crovetto, C., Ferrari, M., Giusberti, G., Longo, L., Peretto, C. \& Vianello, F. 1992, Nuove ricerche nel giacimento paleolitico di Isernia La Pineta (Molise). Rivista di Scienze Preistoriche, XLIV (1/2): 3-41. (in Italian) ("New researches in the palaeolithic site of Isernia la Pineta, Molise”).

Barker, G. 1989, Forme e sistemi d'insediamento nella Valle del Biferno nel II millennio. Origini XIV: 131-139. (in Italian) "Forms and settlement systems in the Biferno Valley in the II millennium”.

Barker, G. 1995a, A Mediterranean Valley. Landscape \& Annales History in the Biferno Valley. Leicester University Press, Leicester, 351 p.

Barker, G. 1995b, The Biferno Valley Survey. The Archaeological and Geomorphological Record. Leicester University Press, Leicester, 176 p.

Boëda, E. 2013, Techno-logique et technologie: une paléo-histoire des objets tranchants. @rchéo-éditions, Paris, 266 p. (in French) (“Techno-logic and technology: a paleohistory of sharp objects").

Cazzella, A., Colombo, D., Modesto, R., Lucci, E., Fatica, A. \& Mironti, V. 2017, Pesco la Messa e Murgia Quadra, Frosolone, Isernia. Notiziario di Preistoria e Protostoria, 4.II: 21-34. (in Italian) ("Pesco la Messa and Murgia Quadra, Frosolone, Isernia”). 
Cazzella, A., Lucci, E., Mironti, V. \& Modesto, R. 2018a, Il “Molise Survey Project”. Dinamiche di frequentazione di alcuni rilievi dell'Appennino durante diverse fasi della preistoria. In: Atti del $38^{\circ}$ Convegno Nazionale sulla Preistoria Protostoria e Storia della Daunia (Gravina, A., Ed.), San Severo: 167-183. (in Italian) ("The "Molise Survey Project”. Dynamics of attendance of some elevations of the Apennines during different phases of prehistory”)

Cazzella, A., Lucci, E., Modesto, R. \& Mironti, V. 2018b, Prehistory at high altitude: New surveys in the central-southern Apennines. Antiquity, 92(366), E3. doi:10.15184/aqy.2018.248.

Coltorti, M., Cremaschi, M., Delitala, M.C., Esu, D., Fornaseri, M., McPherson, A., Nicoletti, M., Van Otterlo, R., Peretto, C., Sala, B., Schmidt, V. \& Sevink, J. 1982, Reversed magnetic polarity at Isernia La Pineta, a new lower paleolithic site in Central Italy. Nature, 300: 173-176.

Cremaschi, M. \& Peretto, C. 1988, Le sols d'habitat du site paléolithique d'Isernia La Pineta. L'Anthropologie 92/4: 1017-1040. (in French) (“The living space soils of the Palaeolithic site Isernia La Pineta”)

Grimaldi, S., (Ed.), 2005, Nuove ricerche sul Paleolitico del Molise. Materie prime, industrie litiche, insediamenti. Centro Europeo di Ricerche Preistoriche, Collana Ricerche, 2, Isernia, 126 p. (in Italian) ("New researches on Palaeolithic in Molise. Raw materials, lithic industries, settlements”)

Ialongo, N. 2007, Il Fucino nella Preistoria. In: Grandi Contesti e problemi della Protostoria Italiana, 10 (Peroni, R., Ed.). All’insegna del Giglio Editore, Firenze, 344 p. (in Italian) ("The Fucino in prehistory")

Lock, G.R. 2008, Change and continuity in surface survey data exploring thresholds in the Sangro Valley. In: Archaeology and Landscape in central Italy. Papers in memory of John A. Lloyd, (Lock, G.R., \& Faustoferri, A., Eds.), Oxford University School of Archaeology Monograph, 69, Oxford: 33-46.

Lock, G.R., \& Faustoferri, A. 2008, The Sangro Valley Project: an outline. In: Archaeology and Landscape in central Italy. Papers in memory of John A. Lloyd, (Lock, G.R., \& Faustoferri, A., Eds.), Oxford University School of Archaeology Monograph, 69, Oxford: 23-24.

Lucci, E., Mironti, V., Modesto, R. 2016, Nuove indagini di superficie nell’Alta Valle del Biferno: metodologia applicata e dati dalla campagna di ricognizione del 2015. In: Atti del $36^{\circ}$ Convegno Nazionale sulla Preistoria Protostoria e Storia della Daunia (Gravina, A., Ed.), San Severo: 159-180. (in Italian) ("New surveys in the High Biferno Valley: applicated methodology and data from the 2015's survey campaign”)

Minelli, A., Peretto, C. 2000, Industria litica di Isernia La Pineta (Molise). Caratteristiche tecno-tipologiche, frequenza e distribuzione areale nell'archeosuperficie $3^{\circ}$ del I settore di scavo. Rivista di Scienze Preistoriche, L: 15-37. (in Italian) ("Lithic industry of Isernia la Pineta (Molise). Techno-typological feautures, frequence and spatial distribution on the archaeosurface 3 of the I exacavation sector")

Peretto, C., (Ed.), 2012, L'insediamento Musteriano di Grotta Reali. Rocchetta a Volturno, Molise, Italia. Museologia Scientifica e Naturalistica 8/2, Annali dell’Università di Ferrara, 163 p. (in Italian) (“The Musterian settlement of Grotta Reali: Rocchetta a Volturno, Molise, Italy”) 
Peretto, C., (Ed.), 2013, Isernia La Pineta. Cosmo Iannone Editore, Isernia, 214 p.

Peretto, C. \& Minelli, A., (Eds.), 2006, Preistoria in Molise: gli insediamenti del territorio di Isernia. Centro europeo di ricerche preistoriche, Collana Ricerche, 3. Aracne Editore, Isernia, 416p. (in Italian) (“Prehistory in Molise: settlements of the Isernia's territory”)

Peretto, C., Arzarello, M., Bahain, J.-J., Boulbes, N., Dolo, J.-M., Douville, E., Falguères, C., Frank, N., Garcia, T., Lembo, G., Moigne, A.-M., Muttillo, B., Nomade, S., Pereira, A., Rufo, M.A., Sala, B., Shao, Q., Hohenstein, U.T., Tessari, U., Turrini, M.C. \& Vaccaro, C. 2016, The Middle Pleistocene site of Guado San Nicola (Monteroduni, Central Italy) on the Lower/Middle Palaeolithic transition. Quaternary International, 411(B): 301315. doi:10.1016/j.quaint.2015.11.056.

Puglisi, S.M. 1959, La Civiltà Appenninica. Origine delle comunità pastorali in Italia. Sansoni Editore, Firenze, 116 p. (in Italian) ("The Apenninic Culture. Origin of the pastoral communities in Italy”)

Sprengel, U. 1971, La pastorizia transumante nell'ambiente dell'Italia centro-meridionale. Marburger Geographische Schriften 51, Marburg, 265 p. (in Italian) “Transhumant pastoralism in the environment of central-southern Italy”.

Vezzani, L., Ghisetti, F. \& Festa, A. 2006, Geological map of Molise (illustrative notes), Selca Editore, Firenze, 87 p.

Vilmercati, M. 2017, Analisi tecno-morfo-funzionale dell'industria litica del saggio F nel sito Neolitico di Venafro (IS). Sapienza Università di Roma, Thesis MA (Scienze Archeologiche), Rome, unpublished, 67 p. (in Italian) ("Techno-morfo-functional analysis of the lithic industry of sector F in the Neolithic site of Venafro (IS)”) 